Nevena Krasulja ${ }^{1}$

Univerzitet Union - Nikola Tesla,

Faklutet za poslovne studije i pravo

Milica Vasiljević Blagojević ${ }^{2}$

Univerzitet Metropolitan, Fakultet za Menadžment

Ivana Radojević ${ }^{3}$

Univerzitet Metropolitan, Fakultet za Menadžment
SCIENTIFIC REVIEW ARTICLE doi:10.5937/ekonomika1502131K

Received: January 08, 2015

Accepted: March 23, 2015

\title{
WORKING FROM HOME AS ALTERNATIVE FOR ACHEVING WORKE-LIFE BALANCE
}

\begin{abstract}
In this paper, the authors are addressing the issue of family-work balance, as well as the connection between this phenomenon and working from home. The basic, initial point is that the desired balance can be achieved if the employees are provided with more flexible work schemes, one of which is having the option to perform their work from home. According to the forecasts regarding the work place of the future, employees from almost all demographic, cultural and social groups decided that the trend of the life being reduced to work only, the motto , live to work", is obsolete. The expression ,,live to work" implies the full commitment of individuals to their work, which they deem the „centre“ of their lives. Today, employees are not only employed in an organization, they have several roles which should be brought to a mutual balance. The expression „,work - life balance" which is the outline of this paper, means establishing a balance between the professional and private (family) life. There are more and more employees who do not want to feel the work pressure after work hours, especially those belonging to younger generations. The goal of this paper is to present the main future challenges of the managers worldwide, that is, motivation of employees. It is deemed that a person will stop self-sacrificing or investing their efforts just for money, but will be prepared to do so for other immaterial aspects (Gijic, Jovic, Reko, 2013). The basic methods used in this paper were analysis, synthesis and comparative method. The analysis and synthesis method, as the basic methodological means, is applied throughout the whole paper, while the comparative method is applied in order to compare the results obtained by the researchers up to this day.
\end{abstract}

Key words: HR maganement, work e-home balanse, work from home

\footnotetext{
${ }^{1}$ nevenakrasulja@gmail.com

2 milica.vasiljevic@metropolitan.ac.rs

3 ivana.radojevic@metropolitan.ac.rs
} 


\title{
РАД ОД КУЋЕ КАО АЛТЕРНАТИВА ЗА ПОСТИЗАЫЕ ПОСЛОВНО - ПОРОДИЧНОГ БАЛАНСА
}

\begin{abstract}
Абстракт
Аутори се у раду баве дефинисањем проблематике породично - пословног баланса, као и повезаности овог феномена са радом од куће. Основна теза од које се полази јесте да се жељени баланс може постићи уколико се запосленима пруже флексибилније радне шеме, а као једна од юих, и могућност да свој посао обављају од куће. Према предвиђањима везаним за радно место будућности, запослени из готово свих демографских, културолошких и социолошких група определили су се да тренд по коме се живот своди само на рад мото “живи да би радио” више није актуелан. Под термином „жсии да би радио“ подразумева се потпуна посвећеност појединца послу који он сматра „центром “ свог живота. Данас запослени више нису само запослени у организачији, они “играју” више улога које је потребно међусобно помирити. Термин "жорк лифе баланиее", који је окосница овог рада, представља успостваљање равнотеже између пословног и приватног (породичног) живота. Све је већи број запослених, посебно када се ради о припадницима млађих генеращија, који не желе да осећају притисак посла по завршетку радног времена.Циь овог рада је да представи главне изазове руководилаца широм света у будућности, а то је мотивачија запослених. Сматра се да особа више неће подносити жртву или напор само због новца колико ће на то бити спремна због других нематеријанихмомената (Гијић, Јовић, Реко, 2013). Основне методе које су коришћене у овом раду су анализа и синтеза и компаративни метод. Метод анализе и синтезе, као основно методолошко средство, користи се у иелом раду, док је компаративни метод коришћен у сврху поређена резултата до којих су истражсивачи до данас дошли.
\end{abstract}

Кључне речи: менаимент људских ресурса, рад од куће, баланс.

\section{Introduction}

In the modern business world, employees are finding it more difficult to adjust their work and family duties. For that reason, they become more stressed and less motivated. They often change workplace and do not come to work, which results in less productivity. It is completely logical to expect that the consequences of such behavior will have an effect on the organizations they work for and will reflect indeed on their performance. How to attract and how to keep qualified personnel are, therefore, two key issues today. A person never will bring a great sacrifice or effort for the money, but because of some other, intangible moments. Inspiration, afflatus, a higher goal and purpose do not come from money (Gijić, Jović, Reko, 2013).

Modern organizations have become aware that they practically do not exist without their employees. So, an increasing number of them are trying to find different ways of making work hours more pleasant for their employees as well as they are trying to help their employees overcome the inner conflicts that arise from their intertwined duties at work and at home. One of the alternatives is to give employees an opportunity to work from home. This 
issue becomes especially significant if two undeniable facts are recognized: firstly, the time of an employee within a traditionally structured organization is a matter of the past; secondly, modern employees are increasingly opting for the motto "work in order to live". It should be mentioned also that there is no permanent psychological contract between an organization and its employees any longer, in terms of guaranteed jobs. Therefore, employees change a lot of jobs during their professional careers in search for the one that would provide them the best prospective for achieving personal goals.

Accordingly, the authors will define and discuss the work-life balance and the issue of working from home in this paper. Their thesis is that the desired balance can be achieved if employees are offered some flexible work schemes and a possibility to work from their home. The authors have provided an overview of contemporary references which can illustrate and corroborate the above-mentioned issue.

\section{Definig the term "work - life balance"}

In our modern society, characterized by a huge gap between the professional and private/family life, the issue of balance between these completely separate segments is turning into a pressing matter. Trends such as aging of the workforce on the global level, an enormous and ruthless competition, a decision made by the contemporary population to put work in the second place, have made this problem even more relevant (Friedman, Greenhaus, 2000).

There is no doubt that the twenty-first century employees have a greater need to strike a balance between their work and family life. According to some estimations related to a workplace of the future, employees within almost all demographic, cultural and social groups have reported that the motto "live in order to work" is not popular any more. Surveys also show that inability to achieve the desired balance is one of the main reasons why one leaves the workplace, i.e. resigns (SHRM, 2008).

A propos the very term "work-life balance", it can be defined as a state of equilibrium between demands within an organization, on one hand, and those at home, on the other (Friedman, Greenhaus, 2000).

'Work-from-home' is becoming an increasingly conventional way of employment. According to SIPP the share of the population working from home has tripled in the period of 3 decades and in the period 1997-2010 there is recorded an increase of over 4 Million in home-based workers (Mateyka, Rapino, Landivar, 2012).

In such a situation, the most suitable solution to this challenge, which is not simple at all, should be found - how to play the role of a professional and family woman/man in the most successful way in terms of work and in the least harmful way in terms of family life. A large number of employees complain most frequently that they experience so-called role conflict, i.e. a situation when they do not fulfil their needs as individuals in either of segments in the way they want and that would satisfy them.

Although this issue became more relevant in the last couple of decades, it is important to mention that some programs existed even in the 1930s. In the 1970s, Kanter termed the "myth of separate worlds", trying to point out that work and private life are inseparable aspects in one's life (Kanter, 1977). However, regardless of numerous pioneer attempts, companies started introducing actual and target programs on work-life balance at the end of the 1980s and the beginning of 1990s. Many of them supported exclusively women 
with children at the beginning. But, these programs are less gender-orientated today. It is a general attitude that all employees, regardless of their sex, should have a private life, family, children and homes. In addition, it is equally important to everybody to possess a dose of flexibility and control over these two separate aspects of their lives. Generally speaking, the demands any individual should address are increasing. This leads to an elevated level of stress, a decrease in productivity, physical and mental diseases and absence from work et al. The above-mentioned undesired psycho-physical effects unfortunately have become omnipresent among employees in the majority of modern organizations. Workforce under a lot of pressure because of diverse obligations and demands starts getting ill, which results in reduced productivity.

Meaning of the term 'work-life' balance surely cannot be defined in one way. For the purpose of better understanding it, one should take its aspects into consideration (Swift, 2002): conflicts experienced by an individual because she/he is trying to strike a balance between her/his duties at work and at home; 'work-life balance' from the viewpoint of the employer, i.e. the employer considers that the individual must fulfill her/his obligations at work first, regardless of the fact that the organisation, on the other hand, respects to a great extent its employee as an individual who has her/his personal life; the programs implemented by the employer in order to help the individual to harmonize her/his professional and private duties (so-called giving flexibility); the organizational culture of a company which can respect responsibilities and duties of an employee to a larger or smaller extent when her/his private life is at issue.

However, the problem of achieving balance between work and family becomes even more complex when one realizes the fact that a large number of organizations are structured today in a way to solely suite management and to achieve organizational goals. No matter that a workplace has changed a number of its characteristics in comparison to its equivalent from the previous century (including new and modern organizational forms, a possibility to work from home, etc.), it seems that employers still do not fully understand that demanding interaction between work and family. Today's academic literature shows that more than 200 articles on this subject-matter have been published, and all of them study the same problem - how to separate work and family/private life and how to reduce tension which, due to their unbreakable bond, individuals feel (MacDermid, 2005).

As already mentioned, the conflict between work and family life is associated with a number of adverse outcomes, both for an individual and an organization. Given that different, incompatible demands cause it, an individual goes through a state of high tension when trying to fulfil all that is expected. Therefore, it is logical to argue that the work-life balance cannot be achieved until the very notion of this conflict is fully understood and explained. Only then will both organizations and individuals know what they are dealing with, and suitable solutions will be applied accordingly (Stroh, 2005). Another fact that speaks in favour of the above-mentioned claims is that most of the researchers on this issue are focused on the organization to a larger extent and less on the individual. Likewise, the studies so far have not yet provided a critical amount of sufficient information that would assist organizations to create an effective set of measures that would help both sides (Cummings, Jones, 2003). 


\section{Modern organisation and balancing work and family life}

Modern business realities shows that the traditional workplace is a matter of the past. There are virtually no more employees who think in the "Weberian" mode. The situation in their environment has changed the way people approach their work and earn their livelihood. Firstly, technology is developing faster now - individuals have the most sophisticated softwares at their disposal; they become members of social networks et al. Then, there is an increasing number of households with several sources of income - the traditional role of women as family members exclusively in charge of household has changed completely. Diverse needs of the employees belonging to different age groups become more manifest; for example, employees who are less than 35 years old prefer flexible work hours. Also, more and more employees make a conscious decision, even at the expense of their income, to take care of their children, elderly family members and household a greater part of the day. Trends suggest that the number of single-member and single-parent families is constantly on the rise. Of course, all these changes have affected the organizations that now are not considered to be sufficiently competitive if they do not care about the quality of their employees' life and wider community in general.

Ergo, organisations are forced in this new situation to find ways to reduce that feeling of pressure their employees are feeling more and more. In order to ensure a higher level of the work-life balance, most organizations adopt some of the following measures (Kersley et al., 2005): flexible work hours that allow the employee to begin working when it would be the most appropriate and to finish work day when the employee decides, of course, provided that the required number of hours as well as all tasks are completed; working from home; the possibility to share the entire amount of work with a colleague; programs of paid leave (maternity leave, sick leave due to illness/death of a family member, absences after a strenuous period of work, stress, etc.); financial participation of the organisation in their employees' childcare or care of elderly family members.

Which of these approaches will be adopted by the organization depends upon many factors. However, the organization will implement, as the most appropriate approach, the one that enables it to attract new candidates without any difficulty in any period of time, and that reduces at the same time, even in case of people who are already employees, the conflict that arises between work and family.

The organization must not remain focused solely on family obligations and responsibilities. Human beings are "social animals". Therefore, the time that the employee spends socializing with friends or on favorite hobbies and sports activities should not be neglected as well. (Tausig, Fenwick, 2001).

There is no doubt that every measure taken by the organization for the purpose of reducing the discussed conflict and increasing the balance would reflect on the growth of performance, productivity and effectiveness. The previous experiences have shown that employees have a higher level of commitment to their organization and to their work in situations where they have an opportunity to choose flexible work hours, to work from home, to decide on their own when their work hours will be day by day during their workweek (Halpern, 2005). A similar situation is with business managers: by making deliberate choices about which opportunities they'll pursue and which they'll decline, rather than simply reacting to emergencies, leaders can and do engage meaningfully with work, family, and community (Groysberg and Abraham, 2014). 
When organizations have established some practices that will help their employees to achieve the necessary balance, the benefit to the entire organization will become visible. Their employees will become committed to their work in the right way and they will make more efforts. This contributes to the growth of performance on all organizational levels. It is certain that the employees who feel that they have control over their time, life and obligations will be indeed happier and will not look for another organization where they can achieve the desired balance. The stated claims can be easily explained by the theory of social exchange (Blau, 1964). When an employee in an organization feels good and respected, it is reciprocated with the need to express gratitude and respect in return. If this quid pro quo is understood as part of social exchange, it is quite logical that those organizations who recognize that their employees have their private/ family lives as well will get significant benefits in return - a higher level of commitment, satisfaction, motivation, a lower level of abstention et al.

However, the behavior of employees, as far as various programs implemented by the organizations they work for are concerned, is not always as expected. It has been confirmed that there is a large number of employees who do not feel the need to show their appreciation to the organization for the perks they get from it. Instead, they treat everything that the organization provides them with as "given", something they automatically deserve. Some researchers also report that a large number of employees are not aware or informed of the benefits they are entitled to. Then, there are employees who are not willing to use the benefits of these programs designed for balancing work and family life; male part of the population, especially those men who may be labelled as "career men" and /or are positioned higher in the hierarchy, very rarely take leaves when a child birth, education of their children or solving family problems are involved. In their opinion, such behavior indicates a lack of commitment to the job, leaving colleagues in the lurch, an impediment on their way up the ladder etc. The situation is quite different when it comes to working women (Lewis, Smithson, 2001).

It should not be forgotten that, in spite of all these trends, a lot of organizations are still well-known for their culture of overtime work. Their employees know from the very moment they start working for them that they cannot count on the aforementioned benefits at all; these organizations themselves discourages their employees in advance. As though the business culture of these organizations does not recognize that their employees have their own family and private lives beside their work. Some completely different qualities are highly valued - permanent presence at work, willingness to work overtime. The employees who fit into this environment without any opposition are considered to be loyal, competitive and to have more requirements for advancing.

However, what the experience indisputably shows is that the organizations that offer to their employees the work-life balance programs win over employees extremely easier and the one already working for them do not leave them hastily. Most employees today favor more those organizations that provide them with an opportunity to build their careers in a flexible way than the traditional ones where one's career path has been traced in advance.

\section{Working from home as an alternative in achieving a desirable balance}

World Economic Forum (WEF) defines competitiveness as "set of institutions, policies and factors that determinate the level of productivity of a country". Thos suggests that the 
nation is competitive if its population can on a sustainable basis revel in high and rising standard of living with high levels of employment (EC, 2012)

Working from home is gradually becoming everyday life for the majority of occupations and professions in the twenty-first century. Of course, this somewhat abstract way of doing business is getting more and more importance in the era when the work-life balance is being promoted extensively. As it is well known (and it has already been mentioned it), the motto of "live in order to work" has been almost completely modified over the years into its opposite -"work in order to live". Therefore, the governments of many European countries had to consider this matter very seriously; the pressure to work from home, especially by those employees with families, was becoming stronger. On the other hand, working from home definitely seems to be a better solution in the situation when an individual "play" more than one role on a daily basis.

Working from home is constantly on the rise both in Europe and the United States. However, an amount of skepticism is still present - whether working from home is really effective or does it represent some kind of "shirking" far away from the manager's control. But, what can be argued with certainty is this domain give a lot of space for researching.

Technological changes have almost completely erased and changed the relationship between the time spent at work and the time spent at home. In the period before the Industrial Revolution, a great part of the population in Europe and the United States worked from home. Those were season jobs. Then, family members worked as a team and the periods of intense work ended with distinctive, ceremonial celebrations and a longer rest (Gutman 1988).

Industrialization brought a new trend - working at home was replaced by working in an office (or in a factory), so the male part of the population and single women started going to work every day. Since no type of change goes smoothly, this trend was accompanied by certain problems as well. Workers /employees were complaining mostly about the same things as their twenty-first century counterparts. It was difficult for them to accept that they were separated from their families all day and that they had to worked fixed hours (Cowan 1997).

Today's technological changes have generated two categories of employees working from home (Fredriksen-Goldsen, Scharlach 2001). Firstly, there are employees who sell different types of services (i.e. Telemarketers). Their work is under the constant supervision of their management and they work the same shifts at home as they would work in an organization. Other categories of employees are independent and highly educated professionals. Their type of work gives them greater flexibility and autonomy in their work. These employees usually undergo a number of extensive training sessions, which makes them psychologically more focused on their work. They also have higher incomes in comparison to their counterparts from the first category. In order to work, they need peace and privacy since their work involves planning and analyzing; therefore, they have no fixed work hours. Also, some trends suggest that the employees in the domain of information technology are the best candidates for working from home.

Individuals choose to work from their home for various reasons. The most common categories of employees that are willing to work from home are as follows (Hakim, 2000): individuals who begin to work from home after they have finished raising children (forty years old); young people who have just finished college, but have always wanted to start their own business; people who are about to retire and who believe that working from home will give them more in every sense of the word than finding a new job, which is quite difficult 
at their age. A lot of people have decided to work from home because they did not like the atmosphere in their office. In their opinion, they often stayed in their offices and did nothing after they had finished their job, while such a thing rarely happens at home.

Naturally, we should not forget changes in the very environment which have forced many individuals to choose working from home. Re-structuring and re-organising of jobs and the entire organisation have become trends nowadays.

According to Laura Shin, Forbes contributor, the top industries offering remote work opportunities include healthcare, information technology, education, non-profit and philanthropy, and sales and marketing. A wide spectrum of jobs is available for homebased workers, ranging from job titles such as sales representative, senior analyst, nurse case manager, accountant, account executive, to the Web or software developer, and virtual teacher (Shin, 2014).

\section{Advanatages and disadvantages of working from home}

Since obligations at home and at work are intertwined, three types of conflict arise in the twenty-first century employees: a conflict related to time, a conflict related to a high level of stress and a conflict related to behaviour (Grover, Crooker, 1995).

The educated employees who choose to work from home indeed reduce the potential for the outbreak of the first type of conflict given that their working from home, as already mentioned, allows greater flexibility when it comes to the way of doing job. However, in this case, there are some disadvantages. If they add some new obligations at home to the existing responsibilities (it usually happens when working woman are concerned), excessive stress is unavoidable again. The same phenomenon occurs in cases when the work is too demanding, when working from home means longer hours and so on.

Therefore, in order to manage their time successfully, the employees working from home need to set some clear boundaries between family and business commitments. The aforementioned issues are gaining more and more importance, so some authors have even defined and elaborated theso-called theory of setting boundaries (Ashforth, Kreiner, Fugate 2000). In their opinion, the individuals working from home must constantly balance in order not to provoke the disagreeable role conflict.

The employees who work from home must maintain contact with the outside world, their employers, co-workers and clients. The opposite, as well as not setting the clear boundaries, can lead them to professional and social isolation (Felstead, Jewson, 2000).

The employees engaged in some kind of highly professional expert work can face a particular problem related to the role conflict. They are expected to work with more dedication, and their work hours are often very long and flexible. This profile of employees is also distinctive because they are very committed to their work which prevents them, on the other hand, from dedicating themselves to their home and family and even if they are physically present.

Further, working from home can be slowed down by a number of distractions, which would not happen in an organization. In this case, there is no secretary, office or business privacy. Therefore, these employees are forced to eliminate different kinds of diversion while working. It has been established that the lack of understanding comes mostly from home children, family members, neighbors, relatives, as well as others who are under the same roof. 
They often do not realize that working from home requires peace and quiet, both physically and mentally.

Knowing the problems, the practitioners have written a lot of books that provide instructions for self-help and suggest specific strategies. Many of them argue that employees should maintain a strict division between the time for work and the time for family. Also, it is advised that one should thoroughly explain responsibilities to family members and inform them about a schedule everybody should stick to in the course of work hours at home. Phone calls during the "home work hours" should be limited. Sometimes it is even advisable to set imaginary deadlines. One of the recommended strategies is to convene a family meeting. The employee should explain professional commitments to family members in order to shield her/himself and her/his work hours (when they should be "left alone") (Edwards, Edwards1994).

The employees working from home are tempted to resort to many bad habits disturbed sleeping patterns, taking larger quantities of meals more frequently, watching television, reading all the daily newspapers, too long telephone conversations. As far as this, it is even suggested to mark the beginning of working hours in a distinctive way - physical activity, dressing, breakfast and then the beginning of one's workday. So, the whole ritual is essentially very similar to the one the employee would go through if she/he worked in an office (Edwards, Edwards, 1994).

Then there is the issue of isolation. The employees working in the office are not confronted with it at all. Constant interaction with other people in the organization, and even making friends with co-workers, often create a sense of belonging to a group and a sense of loyalty. However, the employees working from home do not have such opportunities. They often suffer from a lack of social contacts. Generally, they are short of opportunities to learn from their co-workers. Of course, depending upon the type of personality and/or work, many will not feel isolated and bad. Some employees have even stated that they work more efficiently and faster at home just because nothing interferes with their work - specific stories told by colleagues, office hubbub, etc. (Nippert-Eng, 1996).

To conclude Work-from-Home represent statistically important factor that affects the level of income satisfaction in two ways. Factor 1 values in the sample range from -2.2 up to +2.0 and they can have both positive and negative impact as long as current ability to work from home has a positive impact. (Krasulja, Radojevic, Zubovic, 2014) For example Bloom et al. (2013) have conducted an experiment in China showing that there is a highly significant $13 \%$ increase in performance from home-working persons as compared to control group.

\section{Conclusion}

In view of all this, it can be concluded that the modern workforce no longer wants to be a "slave to" obligations as imposed by the employer, and this is particularly evident if the above- mentioned features are observed in the generation Y. The employees are not just employees of an organization. They now play multiple roles between which they should strike a balance.

It is completely certain that working from home can represent a great perspective when it comes to solving the issue of the work-life balance. As it has been mentioned, the positive sides are undeniable - flexibility of organizing time during the day, a possibility 
to take care of children and family, a higher degree of casualness. What might be pointed out as a distinct advantage is that this kind of work gives a chance to the employees from the category of professionals to express their creativity better. It is safe to say that there are numerous employees who feel under pressure in an office environment and because of work schemes. Therefore, they achieve worse results within an organization than at home. In this case, the thesis that only satisfied employees contribute to productivity growth of an organization is fully substantiated.

Given that working from home has not become a generally accepted practice yet, the organizations that decide to enable their employees to "take their work home" should establish together with them a system of work, a method of monitoring results, as well as other categories that will ensure that this mode will bring the maximum benefit to both sides. In addition, the employees who are not familiar with the concept should go through the process of training.

Naturally, it should be also mentioned that some professions are not suitable for this type of work (medical doctors, policemen, workers in public administration and the like.). However, they should be given an opportunity to have flexible work hours, which would contribute to their achieving a higher degree of the work-life balance as well.

There is no doubt that organizations may save a lot by allowing their employees to work from their home. Many expenses, particularly those related to the lease of their premises, electric energy consumption, meal allowances and other, can be reduced to a minimum.

The authors are planning to conduct a research in their future work. This research should provide some clear parameters of how many employees (and employers) on the territory of Serbia are at all familiar with the concept of working from home, how many of them have already done that and whether they think that this concept can contribute to a better quality of life.

\section{References}

Ashforth, B. E., Kreiner, G. E., \& Fugate, M. (2000) All in a day's work: Boundaries and micro role transitions. Academy of Management Review, 25 (3), 472-491.

Blau, P. (1964) Exchange and power in social life. New York: Wiley.

Bloom, N., Liang, J., Roberts, J., \& Ying, Z. J. (2013) Does working from home work? Evidence from a Chinese experiment (No. w18871). National Bureau of Economic Research.

Cowan, R. S. (1997) A Social History of the American Technology. New York: Oxford University Press.

Cummings, T. G. \& Jones, Y. (2003) Conference theme: Creating actionable knowledge. (Academy of Management call for submissions)

EC, 2012, European Competitiveness Report - Raping the Benefits of Globalization. European Commission.

Edwards, P., Edwards, S. (1994) Working from Home: Everything You Need to Know about Living and Working Under the Same Roof. New York: Putnam.

Felstead, A., Jewson, N. (1996) Homeworkers in Britain. London: HMSO. 2000. In Work, at Home: Towards an Understanding of Homeworking. London: Routledge.

Fredriksen-Goldsen, K. I., Scharlach. A. (2001) Families and Work: New Directions in the 
Twenty-First Century. New York: Oxford University Press.

Friedman, S. D., Greenhaus, J. H. (2000) Work and family-Allies or enemies? What happens when business professionals confront life choices. New York: Oxford University Press.

Gijić, N., Jović-Bogdanović, A., \& Reko, K. (2013). Najmoćniji motivatori u savremenom poslovanju. Ekonomika, 59(3), 96-110.

Grover, S. L., \& Crooker, K. J. (1995). Who appreciates family $\square$ responsive human resource policies: The impact of family $\square$ friendly policies on the organizational attachment of parents and non $\square$ parents. Personnel psychology, 48(2), 271-288.

Groysberg, B., \& Abraham, R. (2014) Manage Your Work, Manage Your Life. Harvard Business Review. Retrieved from http://www.wbsociety.org/wp-content/ uploads/2014/03/Harvard-Business-Review_Manage-your-work-Manage-your-life. $\operatorname{pdf}(3.1 .2015$.

Gutman, H., E. (1988) Work, Culture and Society in America. 125-137 in On Work: Historical, Comparative and Theoretical Approaches, edited by R. E. Pahl. New York: Blackwell.

Hakim, C., (2000) Work-Lifestyle Choices in the 21st Century. New York: Oxford University Press.

Halpern, D. F. (2005). How time-flexible work policies can reduce stress, improve health, and save money. Stress and Health 21(3), 157-168.

Kanter, R. M. (1977) Work and family in the United States: A critical review and agenda for research and policy. New York: Russell Sage Foundation.

Kersley, B., Alpin, C., Forth, J., Bryson, A., Bewley, H., Dix, G., Oxenbridge, S. (2005) Inside the workplace: First findings from the 2004 Workplace Employment Relations Survey. London: Department of Trade and Industry.

Krasulja, N., Zubović, J., \& Radojević, I. [2014]. Uticaj 'rada od kuće' na zadovoljstvo prihodima. Industrija, 42(3), 129-140.

Lewis, S., \& Smithson, J. (2001) Sense of entitlement to support for the reconciliation of employment and family life. Human Relations, 54 (11), 1455-1481.

MacDermid, S. M. (2005) (Re) Considering conflict between work and family. In E. E. Kossek \& S. J. Lambert(Eds.),Work and life integration: Organizational, cultural, and individual perspectives: 19 - 40. Mahwah, NJ:Erlbaum.

Mateyka, P. J., Rapino, M., Landivar, L. C. (2012) Home-Based Workers in the United States: 2010. US Department of Commerce, Economics and Statistics Administration, US Census Bureau.

Nippert-Eng, Christina E. (1996) Home and Work: Negotiating Boundaries through Everyday Life. Chicago: University of Chicago.

Stroh, L. K. (2005) Work and life integration: Organizational,cultural, and individual perspectives: XVII-XVIII. Mahwah, NJ: Erlbaum.

Swift, L. (2002) Work-life balance important in relief world, too. Reuters AlertNet. Retrieved January 30, 2003, from http://www.alertnet.org/thefacts/reliefsources (20.12.2014.) 
Tausig, M., \& Fenwick, R. (2001). Unbinding time: Alternate work schedules and worklife balance. Journal of Family and Economic Issues, 22(2), 101-119.

WEF, (2012) The Global Competitiveness report 2012-2013. Ed. Schwab, K, World Economic Forum

Worklpace flexibility in 21st Century: Meeting the Needs of the Changing Workforce, (2008) Society for Human Resource Management (SHRM)

Shin, L. (2014) Work From Home: The Top 100 Companies Offering Flexible Jobs In 2014. Retrieved from http://www.forbes.com/sites/laurashin/2014/01/17/workfrom-home-the-top-100-companies-offering-flexible-jobs-in-2014/ (2.1.2015)

Zubović J, \& Bradić-Martinović, A. (2014) Competitiveness of Nations in Selected SEE Countries. Procedia Economics and Finance, 8, 755-762. 